Brit. J. vener. Dis. (1966), 42, 178.

\title{
EFFECTS OF GRISEOFULVIN IN EXPERIMENTAL RABBIT SYPHILIS*
}

\author{
BY \\ TERUHIKO HASEGAWA \\ Kyoto, Japan
}

We have previously reported the effects of some antibiotics on experimental rabbit syphilis (Fujita, Asada, and Amawashi, 1962). The recent resurgence of infectious syphilis has led us to look for more effective anti-luetic agents. From this point of view we are studying the ultrastructure of spirochaetes (Hasegawa, Sasahira, and Matsuura, 1965; Hasegawa and Sasahira, 1965; Hasegawa, Komura, and Sasahira, 1966).

Griseofulvin is an antifungal antibiotic produced by Penicillium griseofulvum, and is widely used in the therapy of superficial fungal dermatoses. Its origin, like penicillin from a mould of the Penicillium group, made it of interest to determine whether griseofulvin is also effective against spirochaetes. Its effect on spirochaetes was first reported by Meinicke (1961a), who found that griseofulvin had no treponemistatic effect against Reiter spirochaetes. Meinicke (1961b) also reported that griseofulvin had no effect on experimental syphilis in the rabbit. Brodey (1962) reported that the clinical picture of patients with secondary syphilis who were given Griseofulvin was somewhat improved. He asserted that no one knew its effect on secondary syphilis, and that its effect on syphilis should be studied.

From some of these results, it became important to try the application of Griseofulvin in secondary syphilis, and we therefore used it in the treatment of two such cases.

\section{Case Reports}

Case 1, a 28-year-old single man, was seen in the dermatological clinic of Kyoto University in June, 1964, with a complaint of eruptions in the genital area. The lesions were reddish-brown papules on the glans penis, scrotum, and perianal region, and were diagnosed as condylomata lata.

Dark-ground examination of serum from the papule showed Treponema pallidum. A serological test for syphilis was strongly positive.

\footnotetext{
* Received for publication December 14, 1965.
}

Treatment.-700 mg. of ultra-fine Griseofulvin was given daily and Terracortril was applied locally. After 7 days' therapy, the lesions became dry and decreased in size. Terracortril was then stopped but griseofulvin was continued.

Result.-After one month's treatment the lesions had almost disappeared and were normal in appearance. The patient was not seen thereafter.

Case 2, a 31-year-old married man, was seen in our clinic with a complaint of eruptions on the genital area in October, 1964. Condylomata lata were also diagnosed.

Treatment. $-700 \mathrm{mg}$. ultra-fine griseofulvin was given daily, but after 5 days' therapy the lesions increased, and dark-ground examination showed $T$. pallidum in serum from the papule. Therefore griseofulvin therapy was avoided, and syncillin (DL- -Phenoxyethyl Penicillin) was given.

Result.-The lesions soon became dry and disappeared, the titre of a serological test for syphilis decreased gradually.

Comment.-A dramatic effect was obtained with griseofulvin in Case 1, but not in Case 2. It thus became important to study its effect in vivo. The present report deals with the effects of griseofulvin in experimental rabbit syphilis, which were somewhat different from the results obtained by Meinicke (1961b).

\section{Material and Methods}

A suspension of $T$. pallidum (Nichols' strain) containing five treponemes per microscopic field was inoculated into the testicles of rabbits with a body weight of about $2.5 \mathrm{~kg}$. 14 days after the presence of living treponemes and orchitis were confirmed, antibiotic therapy was started and continued for 10 days.

Tablets of ultra-fine griseofulvin were ground powderfine in a blender. In each experiment, griseofulvin dissolved in water was given orally at the rate of 250 or 
$500 \mathrm{mg}$. daily. Two rabbits were given $250 \mathrm{mg}$. griseofulvin and the other two $500 \mathrm{mg}$. for 10 days. As a control, similarly infected rabbits were left untreated and observed. After 11 days, all the animals were killed, and the testicles removed aseptically. The testicles from each rabbit were minced with scissors, and physiological saline was added (1-2 ml. per gramme of tissue). Darkground examination for $T$. pallidum was performed on this fluid and $1 \mathrm{ml}$. was injected intracutaneously on the clipped backs of two healthy rabbits. As a control of susceptibility to re-inoculation, $1 \mathrm{ml}$. of a suspension of $T$. pallidum (about five motile treponemes per microscopic field) freshly obtained from the testes of rabbits infected 14 days previously was also injected intracutaneously into a healthy rabbit.

Animals were examined daily for the development of papules and chancres. Testicular tissue from each rabbit was fixed in 10 per cent. formol saline and the specimens were stained with haematoxylin and eosin and used for histological study.

\section{Results}

The main results are summarized in the Table. The general condition of the rabbits was not influenced by the administration of griseofulvin. During the first 4 days, the orchitis increased in spite of griseofulvin therapy, and was almost the same as that of the untreated rabbit; the testicles were firm in all instances. After 5 days' treatment, the orchitis began to decrease. There was no difference between the animals given $250 \mathrm{mg}$. griseofulvin and those given $500 \mathrm{mg}$. After 10 days' therapy, the testes of one rabbit given $500 \mathrm{mg}$. griseofulvin $(\mathrm{C})$ became almost normal in appearance. Meinicke (1961b) reported that syphilitic orchitis was not influenced by 8 days' treatment with griseofulvin. Giant testicular syphilomata were present in the untreated rabbit. Dark-ground examination of testicular fluid did not show up $T$. pallidum in the animals treated with griseofulvin, but was positive in the control animal.

Histological examination of testes from the treated rabbits showed a heavy and diffuse infiltration of lymphocytes and plasma cells. Desquamation and necrosis of epithelium was also found. In Rabbit C (Table), the microscopical findings were almost the same as with other griseofulvin-treated animals, though the orchitis was markedly decreased. The testes of the untreated rabbit showed severe necrosis of epithelium, thrombosis, and extravasated fresh blood.

Rabbits inoculated intracutaneously with material from the testes of three of the four rabbits treated with griseofulvin developed reddish papules, which became ulcerated chancres in which $T$. pallidum were found by dark-ground examination 19 days after inoculation. Material from the infected rabbit left untreated as a control did not produce lesions, but a freshly prepared suspension of $T$. pallidum from a 14-day-old orchitis produced dark-field positive lesions (Table).

\section{Discussion}

Penicillin has been found to have an excellent effect on testicular syphilomata in the rabbit (Fujita and others, 1962).

Orchitis was also decreased with griseofulvin therapy, but these changes were not remarkable compared with those produced by penicillin therapy. Griseofulvin is not clinically effective in rabbit syphilis because inoculation of material from treated animals produced dark-field positive lesions.

TABLE

EFFECTS OF GRISEOFULVIN ON EXPERIMENTAL SYPHILIS IN THE RABBIT

\begin{tabular}{|c|c|c|c|c|c|c|}
\hline Rabbits & $\begin{array}{l}\text { Dose of } \\
\text { Griseofulvin } \\
\text { (mg.) }\end{array}$ & $\begin{array}{l}\text { Swelling of } \\
\text { Testes }\end{array}$ & Spirochaetes & Histology & Re-inoculation & Spirochaetes \\
\hline $\mathbf{A}$ & \multirow{2}{*}{250} & Decreased & Not found & $\begin{array}{l}\text { Epithelial necrosis } \\
\text { Lymphocytes }\end{array}$ & & \\
\hline B & & Decreased & Not found & $\begin{array}{l}\text { Epithelial necrosis } \\
\text { Lymphocytes }\end{array}$ & Chancre & Positive \\
\hline $\mathrm{C}$ & \multirow{2}{*}{500} & Remarkably decreased & Not found & $\begin{array}{l}\text { Epithelial necrosis } \\
\text { Lymphocytes }\end{array}$ & & \\
\hline D & & Decreased & Not found & $\begin{array}{c}\text { Epithelial necrosis } \\
\text { Lymphocytes }\end{array}$ & No eruption & Not found \\
\hline \multicolumn{2}{|c|}{$\begin{array}{l}\text { Control } \\
\text { Untreated }\end{array}$} & $\begin{array}{l}\text { Severe swelling } \\
\text { Giant testicular } \\
\text { syphilomata }\end{array}$ & Present & $\begin{array}{l}\text { Necrosis } \\
\text { Thrombosis } \\
\text { Extravasated } \\
\text { fresh blood }\end{array}$ & No eruption & Not found \\
\hline \multicolumn{2}{|c|}{$\begin{array}{c}\text { Control for } \\
\text { Re-inoculation }\end{array}$} & & & & Chancre & Positive \\
\hline
\end{tabular}


Inoculation of $T$. pallidum obtained from an orchitis with severe necrosis or mixed infection often fails. We usually use motile $T$. pallidum freshly obtained from an orchitis of 14 days' duration. Development of lesions after inoculation with $T$. pallidum is also dependent upon the number of organisms injected. These factors may explain the lack of infectivity of material from the untreated rabbit.

It is generally accepted that penicillin interferes with the biosynthesis of cell wall substance in sensitive bacteria (Burrows, 1963). Ginger (1963) reported that muramic acid was found in spirochaetes and postulated that spirochaetes might have a cell wall similar in structure to that of the bacteria. From this result, it is considered that penicillin may interfere with biosynthesis of the cell wall of spirochaetes. Opinion about the cell wall structure of spirochaetes varies (Ryter and Pillot, 1963; Kawata and Inoue, 1964; Listgarten, Loesche, and Socransky, 1963). It is conceivable that the cell wall is the cell envelope (Hasegawa, Komura, and Sasahira, 1966; Hasegawa and Sasahira, 1965).

The anti-treponemal action of arsenic and mercury are due to inhibition of sulhydryl groups. We have reported that weak enzyme activity of ATPase and succinic dehydrogenase were demonstrated in spirochaetes by electron cytochemical methods (Hasegawa, Komura, and Sasahira, 1966). These enzymes were localized at the site of the cell membrane. We suggest that spirochaetes may be killed by inactivation of these energy-yielding enzymes by arsenic and mercury.

How does griseofulvin act on spirochaetes? McNall (1960) reported that griseofulvin inhibited the biosynthesis of nucleic acid. Stanka and Nasemann (1961) reported the inhibition of mitosis in HeLa cells by griseofulvin. Larsen and Demis (1963) reported that griseofulvin had no effect on aerobic and anaerobic respiration. D'Arcy, Howard, Muggleton, and Townsend (1960) described the anti-inflammatory action of griseofulvin in expermental animals. According to their report, griseofulvin inhibited the formation of granulation tissue around subcutaneously implanted cotton pellets, and reduction in skin sensitivity to tuberculosis was found. From these reports, it is difficult to conceive whether griseofulvin is effective against spirochaetes or not. But the most important results are the reduction of orchitis, though griseofulvin was not effective in killing spirochaetes. The anti-inflammatory action described by D'Arcy and others (1960) was also proved by us. We suggest that this action may be due to the effect of inhibition of mitosis.
Antitreponemal agents may inhibit biosynthesis of cell wall material like penicillin, or may inhibit respiration like arsenic. Griseofulvin had neither of these characteristics.

In conclusion, it is suggested that research on the ultrastructure of spirochaetes is an urgent task to elucidate the action of antitreponemal agents at the molecular level,

\section{Summary}

Griseofulvin was used to treat experimental rabbit syphilis. It was found to have an antiinflammatory action, but no effect on spirochaetes. The action of antitreponemal agents including penicillin is discussed.

The author wishes to thank $\mathrm{Mr}$ Amawashi and $\mathrm{Mr}$ Nomura of the Kyoto University Hospital for their kind technical guidance.

\section{REFERENCES}

Brodey, M. (1962). Arch. Derm. (Chicago), 86, 357.

Burrows, W. (1963). "Text-book of Microbiology", 18th ed., p. 238. Saunders, Philadelphia.

D'Arcy, P. F., Howard, E. M., Muggleton, P. W., and Townsend, S. B. (1960). J. Pharm. Pharmacol., 12, 659.

Fujita, T., Asada, Y., and Amawashi, M. (1962). Acta Derm. (Kyoto), 57, 73.

Ginger, C. D. (1963). Nature (Lond.), 199, 159.

Hasegawa, T., Komura, J., and Sasahira, T. (1966). Hautartz, 17, 105.

and Sasahira, T. (1965). J. Electron. Microsc., 14, 338.

2., and Matsuura, S. (1965). Acta med. Sch. Univ. Kyoto, 39, 92.

Kawata, T., and Inoue, T. (1964). Jap. J. Microbiol., 8, 49.

Larsen, W. G., and Demis, D. J. (1963). J. invest. Derm., 41, 335 .

Listgarten, M. A., Loesche, W. J., and Socransky, S. S. (1963). J. Bacteriol., 85, 932.

McNall, E. G. (1960). A.M.A. Arch. Derm., 81, 657.

Meinicke, K. (1961a). Hautartz, 12, 26.

- (1961b). Jbid., 12, 287.

Ryter, A., and Pillot, J. (1963). Ann. Inst. Pasteur, 104, 496.

Stanka, P., and Nasemann, T. (1961). Hautarzt, 12, 468.

Les effets de la griséofulvine dans la syphilis expérimentale chez le lapin

RÉSUMÉ

La griséofulvine a été employé pour traiter la syphilis expérimentale chez le lapin. On a trouvé qu'elle avait une action anti-inflammatoire, mais qu'elle n'avait pas d'effet sur les spirochètes. L'action des agents contre les tréponèmes, y compris la pénicilline, est discutée. 